RESEARCH REPORT

\title{
Central and total obesity in middle aged men and women in relation to lifetime socioeconomic status: evidence from a national birth cohort
}

\author{
C Langenberg, R Hardy, D Kuh, E Brunner, M Wadsworth
}

J Epidemiol Community Health 2003;57:816-822

See end of article for authors' affiliations

Correspondence to:

Dr C Langenberg, MRC

National Survey of Health

and Development,

Department of

Epidemiology and Public Health, University College London, 1-19 Torrington Place, London WCIE 6BT, UK; c.langenberg@

ucl.ac.uk

Accepted for publication 13 June 2003
Study objective: To investigate the influence of social class in childhood, young adulthood and middle age, and intergenerational mobility, on adult central and total obesity.

Design: Prospective, population based, birth cohort study.

Participants and Setting: 1472 men and 1563 women born in 1946 in England, Scotland, and Wales. Outcome measures: Waist-hip ratio, waist-height ratio, waist circumference, and body mass index at age 53 years.

Main results: Father's social class at participant's age 4 years was inversely associated with adult central and total obesity at age 53 years in men and women. For example, the mean difference of waist-hip ratio (95\% confidence intervals) between father's professional social class I and unskilled manual social class $\mathrm{V}$ was $2.6 \%(0.7$ to 4.6$)$ for men and $2.5 \%(0.5$ to 4.4$)$ for women. The effect of father's social class remained after adjustment for participant's own social class in young adulthood and middle age. Both adult social classes were inversely related to obesity among women, but not men, after adjustment for childhood circumstances. Upwardly mobile men and women were less obese than participants remaining in their father's social class and their levels of obesity tended to be between the class they left and the class they joined.

Conclusions: The effect of social class on adult obesity differed according to the stage in the life course at which social class was measured, and gender. Childhood circumstances had enduring influences on adult obesity, although our results on intergenerational mobility indicate potential reversibility of early life disadvantage.
$M$ ean levels of obesity have increased in industrialised countries and are associated with many leading causes of death. ${ }^{1}$ Total obesity and centralisation of fat influence the risk of diabetes, cardiovascular morbidity and premature death. ${ }^{2-6}$ Waist-hip ratio, waist-height ratio, and waist circumference are estimates for the amount of (excess) visceral fat and are strong predictors of coronary heart disease and related risk factors. ${ }^{7}$

Lower childhood and adult social class have both been associated with higher levels of adult obesity. ${ }^{8-15}$ Surprisingly few studies have tried to differentiate the effects of early and adult social class on adult obesity, ${ }^{16-20}$ or investigated the effect of intergenerational social mobility. ${ }^{21}{ }^{22}$ None of these studies used prospective measures of childhood social class or attempted to separate the effects of social class at more than two time points. The only study to include both men and women was unrepresentative of the general population, ${ }^{18}$ and only two studies considered measures of central obesity. ${ }^{16}{ }^{18}$ Questions remain regarding the cumulative influence of lifetime socioeconomic circumstances, the relative influence of early and later life socioeconomic circumstances, and the effect of intergenerational social mobility on adult obesity.

The MRC National Survey of Health and Development is a large UK cohort study of men and women who have been followed up since their birth in March 1946 with prospectively collected data on social class from childhood to adult life. This paper extends our earlier study ${ }^{10}$ by examining the effect of all six social classes in childhood, young adult life and midlife on central and total obesity at age 53 years. Firstly, we ask whether childhood social class had additional effects on central and total obesity at age 53 years once the effects of social class at ages 26 and 43 years were accounted for (and vice versa). Are these effects similar for central and total obesity and do they show the same trend in men and women? Secondly, we ask whether levels of central and total obesity are modified by intergenerational mobility? Does the effect of mobility on obesity depend on father's social class and the extent of upward social mobility?

\section{METHODS \\ Participants}

The Medical Research Council's national survey of health and development (NSHD) is a prospective birth cohort study, consisting of a class stratified sample of a third (5362 births; 2547 women, 2815 men) of all births, that occurred in the first week of March 1946 in England, Scotland, and Wales. Follow up included 21 contacts with the whole cohort from birth to the most recent, when survey members were 53 years of age and 3035 participants (1472 men, 1563 women) provided information and the majority (2989) were interviewed and examined by research nurses at home. Where it was inconvenient for the study member to have a home visit, participants completed a postal questionnaire $(n=46)$. This corresponds to a participation rate of $70.5 \%$ among survivors still resident in England, Wales, or Scotland and $89.6 \%$ for whom contact was attempted. Contact was not attempted for people who had previously refused to take part (648), were living abroad (583), were untraced since last contact at 43 years (266) or had already died (476). The population contacted was still in most respects representative of the original cohort. ${ }^{23}$ 


\section{Anthropometric variables}

At age 53 years measures of weight $(\mathrm{kg})$, height $(\mathrm{cm})$, waist $(\mathrm{cm})$ and hip circumference $(\mathrm{cm})$ were obtained according to a standardised protocol. Weight was measured to the nearest $0.1 \mathrm{~kg}$ with participants wearing light indoor clothing and no shoes. Height was measured to the nearest $0.5 \mathrm{~cm}$, using a portable stadiometer with participants standing without shoes and heels against the wall as tall as possible with the head in the Frankfort plane. Waist circumference was measured at a point midway between the costal margin and the iliac crest and in line with the mid-axilla. To measure hip circumference the greater trochanter was located as the widest part of the hips at the level of the buttock line. In each case, the tape was pulled taut and a measurement to the nearest $1 \mathrm{~mm}$ was taken in mid-expiration with study members standing straight with feet together, arms hanging loosely, and looking straight ahead. Waist-hip ratio (waist circumference $(\mathrm{cm})$ divided by hip circumference $(\mathrm{cm}))$ and waist-height ratio (waist circumference $(\mathrm{cm})$ divided by height $(\mathrm{cm})$ ) were expressed as a percentage. Body mass index (weight $(\mathrm{kg})$ divided by squared height squared $\left(\mathrm{m}^{2}\right)$ ) was used as a measure of total obesity.

\section{Social class and mobility}

Social class was based on occupation according to the registrar general's classification with six categories each (I professional, II intermediate, III skilled non-manual, III skilled manual, IV semi-skilled, V unskilled) for the three time points. Father's occupation was used as an indicator of childhood social class when survey members were 4 years old, or if not available, on his occupation when survey members were aged 7 years $(n=125)$. Social class at ages 26 and 43 years was based on the current or last occupation of the head of the household, using the convention of taking the male over the female occupation when both were employed.

Smoking and physical exercise are possible mediators of the influence of social class on obesity. At age 53 years participants provided information on smoking status, and "current" smokers were distinguished from "previous" and "never" smokers. Information on physical exercise was based on having taken part in any sports or vigorous leisure time activities or having done any exercise in their spare time (not including getting to and from work) in the past four weeks.

\section{Statistical analysis}

The highest social class was used as the reference category, and mean levels of obesity of all other classes were compared with this group. Regression models were used to test the relation between social class at each age, entered as a categorical variable, and each of the obesity measures. Analysis was restricted to participants with information on social class at each of the three time points. We also performed tests for trend to check whether levels of obesity increased linearly with decreasing social class. Multiple regression was used to assess the effect of social class at one time point adjusted for social class at both of the other points. There were statistically significant sex by social class interactions, indicating that the effects of social position at each time point on central and total obesity differed by sex. Consequently all analysis was undertaken separately for men and women and interactions are reported where relevant.

To investigate the effects of participants' upward mobility between father's and adult social class at 43 years on adult obesity, we aggregated the two highest (I and II) and two lowest (IV and V) social classes. We created a social mobility variable with six upwardly mobile categories and four categories representing those who were in the same social class at both time points. Further analysis showed that results from that model were robust when adjusted for smoking and exercise. Too few participants experienced downward intergenerational mobility to allow the investigation of this effect in such detail. A second social mobility variable was therefore created differentiating non-manual from manual occupations at each time point. For both mobility variables, tests were carried out to assess whether obesity varied across categories. Analyses were performed using the computer software Statistical Package for the Social Sciences.

\section{RESULTS}

\section{Father's social class}

Father's social class was inversely associated with all measures of obesity in men and women at age 53 years (table 1) These associations remained significant at the 5\% level after adjustment for both adult social classes, with the exception of waist circumference in men (table 2) This difference between men and women was statistically significant ( $p=0.03$ for test for sex by social class interaction).

Table 1A Unadjusted results for men: mean obesity levels ( $95 \%$ confidence intervals) for professional social class 1 (reference group) and differences in means between each other social class and the reference group

\begin{tabular}{|c|c|c|c|c|c|}
\hline Men & & $\begin{array}{l}\text { Waist-hip ratio } \\
\text { ( } n=1299)\end{array}$ & $\begin{array}{l}\text { Waist-height ratio } \\
(n=1299)\end{array}$ & $\begin{array}{l}\text { Waist circumference } \\
(n=1300)\end{array}$ & $\begin{array}{l}\text { Body mass index } \\
(n=1299)\end{array}$ \\
\hline Father's social class & $\mathrm{n}^{*}$ & $p \leqslant 0.001(p \leqslant 0.001 \dagger)$ & $p \leqslant 0.001(p \leqslant 0.001+)$ & $p=0.0 \angle(p=0.04 T)$ & $p \leqslant 0.001(p \leqslant 0.001 \dagger)$ \\
\hline I professional (reference group) & 76 & $91.7(90.3$ to 93.1$) \%$ & $53.9(52.6$ to 55.3$) \%$ & $95.2(92.8$ to 97.6$) \mathrm{cm}$ & $26.1(25.2$ to 27.0$) \mathrm{kg} / \mathrm{m}^{2}$ \\
\hline II intermediate & 223 & $0.6(-1.0$ to 2.2$)$ & $0.9(-0.7$ to 2.5$)$ & $1.5(-1.3$ to 4.3$)$ & $0.7(-0.3$ to 1.7$)$ \\
\hline III skilled non-manual & 239 & $1.4(-0.2$ to 3.0$)$ & $1.5(0.0$ to 3.1$)$ & $2.0(-0.8$ to 4.7$)$ & $0.9(-0.1$ to 1.9$)$ \\
\hline III skilled manual & 393 & $3.4(1.5$ to 4.6$)$ & $3.1(1.6$ to 4.6$)$ & $3.9(1.3$ to 6.6$)$ & $1.9(0.9$ to 2.9$)$ \\
\hline IV semi-skilled & 282 & $1.9(0.3$ to 3.4$)$ & $2.2(0.6$ to 3.7$)$ & $2.3(-0.4$ to 5.1$)$ & $1.3(0.3$ to 2.3$)$ \\
\hline V unskilled & 86 & $2.6(0.7$ to 4.6$)$ & $2.8(0.9$ to 4.7$)$ & $2.4(-0.9$ to 5.7$)$ & $1.8(0.5$ to 3.0$)$ \\
\hline Adult social class at 26 years & & $p=0.002(p \leqslant 0.001+)$ & $p=0.02(p=0.002 t)$ & $P=0.4\left(p=0.3^{*}\right)$ & $p=0.05\left(p=0.03^{*}\right)$ \\
\hline I professional (reference group) & 137 & $92.6(91.5$ to 93.6$) \%$ & $55.0(54.0$ to 56.0$) \%$ & $97.4(95.6$ to 99.2$) \mathrm{cm}$ & $26.9(26.3$ to 27.6$) \mathrm{kg} / \mathrm{m}^{2}$ \\
\hline II intermediate & 333 & $0.3(-0.9$ to 1.6$)$ & $0.5(-0.7$ to 1.8$)$ & $-0.3(-2.4$ to 1.9$)$ & $0.2(-0.6$ to 1.0$)$ \\
\hline III skilled non-manual & 205 & $0.6(-0.7$ to 2.0$)$ & $0.4(-0.9$ to 1.7$)$ & $-0.3(-2.6$ to 2.1$)$ & $0.2(-0.7$ to 1.1$)$ \\
\hline III skilled manual & 448 & $1.9(0.7$ to 3.1$)$ & $1.7(0.5$ to 2.9$)$ & $1.2(-0.9$ to 3.3$)$ & $0.9(0.2$ to 1.7$)$ \\
\hline IV semi-skilled & 153 & $1.4(-0.1$ to 2.8$)$ & $1.2(-0.2$ to 2.7$)$ & $-0.2(-2.7$ to 2.3$)$ & $0.6(-0.4$ to 1.5$)$ \\
\hline V unskilled & 23 & $1.6(-1.1$ to 4.4$)$ & $1.8(-0.9$ to 4.5$)$ & $0.0(-4.7$ to 4.8$)$ & $-0.3(-2.0$ to 1.5$)$ \\
\hline Adult social class at $\mathbf{4 3}$ years & & $p \leqslant 0.001(p \leqslant 0.001 *)$ & $p=0.02\left(p=0.002^{*}\right)$ & $p=0.3\left(p=0.09^{*}\right)$ & $p=0.1\left(p=0.2^{*}\right)$ \\
\hline I professional (reference group) & 144 & $92.3(91.3$ to 93.3$) \%$ & 54.7 (53.7 to 55.7$) \%$ & $96.1(94.3$ to 97.8$) \mathrm{cm}$ & $26.7(26.1$ to 27.4$) \mathrm{kg} / \mathrm{m}^{2}$ \\
\hline$\|$ intermediate & 548 & $0.7(-0.5$ to 1.8$)$ & $1.0(-0.2$ to 2.1$)$ & $1.4(-0.6$ to 3.4$)$ & $0.6(-0.2$ to 1.3$)$ \\
\hline III skilled non-manual & 119 & $1.7(0.2$ to 3.2$)$ & $1.5(0.0$ to 3.0$)$ & $2.0(-0.6$ to 4.6$)$ & $0.8(-0.2$ to 1.8$)$ \\
\hline III skilled manual & 368 & $2.4(1.2$ to 3.6$)$ & $2.0(0.8$ to 3.2$)$ & $2.4(0.4$ to 4.5$)$ & $1.0(0.2$ to 1.7$)$ \\
\hline IV semi-skilled & 98 & $1.7(0.1$ to 3.3$)$ & $1.8(0.2$ to 3.4$)$ & $1.9(-0.9$ to 4.7$)$ & $0.6(-0.5$ to 1.6$)$ \\
\hline V unskilled & 22 & $3.0(0.2$ to 5.8$)$ & $0.6(-2.1$ to 3.4$)$ & $-0.1(-4.9$ to 4.7$)$ & $-0.6(-2.5$ to 1.2$)$ \\
\hline
\end{tabular}

*Numbers are based on the model including waist-hip ratio and vary only slightly for the other obesity measures. †Test for trend. 
Table 1B Unadjusted results for women: mean obesity levels (95\% confidence intervals) for professional social class 1 (reference group) and differences in means between each other social class and the reference group

\begin{tabular}{|c|c|c|c|c|c|}
\hline Women & & $\begin{array}{l}\text { Waist-hip ratio } \\
(n=1345)\end{array}$ & $\begin{array}{l}\text { Waist-height ratio } \\
\text { ( } n=1342 \text { ) }\end{array}$ & $\begin{array}{l}\text { Waist circumference } \\
\text { ( } n=1347)\end{array}$ & $\begin{array}{l}\text { Body mass index } \\
(n=1337)\end{array}$ \\
\hline Father's social class & $\mathrm{n} \dagger$ & $p \leqslant 0.001\left(p \leqslant 0.001^{*}\right)$ & $p \leqslant 0.001\left(p \leqslant 0.001^{*}\right)$ & $p \leqslant 0.001(p \leqslant 0.001 *)$ & $p \leqslant 0.001\left(p \leqslant 0.001^{*}\right)$ \\
\hline I professional (reference group) & 86 & $79.5(78.1$ to 80.8$) \%$ & $51.1(49.4$ to 52.8$) \%$ & $83.6(80.9$ to 86.3$) \mathrm{cm}$ & 26.5 (25.4 to 27.7$) \mathrm{kg} / \mathrm{m}^{2}$ \\
\hline II intermediate & 228 & $0.1(-1.5$ to 1.7$)$ & $0.6(-1.4$ to 2.6$)$ & $0.4(-0.8$ to 3.5$)$ & $0.1(-1.3$ to 1.5$)$ \\
\hline III skilled non-manual & 260 & $0.6(-1.0$ to 2.2$)$ & $-0.0(-2.0$ to 1.9$)$ & $-0.6(-3.7$ to 2.5$)$ & $-0.6(-1.9$ to 0.8$)$ \\
\hline III skilled manual & 414 & $1.1(-0.4$ to 2.7$)$ & $2.7(0.8$ to 4.5$)$ & $2.8(-0.2$ to 5.7$)$ & 1.5 ( 0.3 to 2.8$)$ \\
\hline IV semi-skilled & 273 & $2.2(0.6$ to 3.8$)$ & $4.3(2.4$ to 6.3$)$ & $5.4(2.3$ to 8.5$)$ & $2.1(0.8$ to 3.4$)$ \\
\hline V unskilled & 84 & $2.5(0.5$ to 4.4$)$ & $3.6(1.2$ to 6.0$)$ & $3.6(-0.3$ to 7.4$)$ & $1.3(-0.4$ to 2.9$)$ \\
\hline Adult social class at 26 years & & $p \leqslant 0.001\left(p \leqslant 0.001^{*}\right)$ & $p \leqslant 0.001\left(p \leqslant 0.001^{*}\right)$ & $p \leqslant 0.001(p \leqslant 0.001 *)$ & $p \leqslant 0.001\left(p \leqslant 0.001^{*}\right)$ \\
\hline I professional (reference group) & 131 & $79.2(78.1$ to 80.3$) \%$ & $51.0(49.6$ to 52.4$) \%$ & $83.15(81.0$ to 85.3$) \mathrm{cm}$ & $26.4(25.5$ to 27.4$) \mathrm{kg} / \mathrm{m}^{2}$ \\
\hline II intermediate & 360 & $0.1(-1.2$ to 1.4$)$ & $0.4(-1.2$ to 2.0$)$ & $0.5(-2.0$ to 3.1$)$ & $0.2(-0.9$ to 1.3$)$ \\
\hline III skilled non-manual & 218 & $1.3(-0.1$ to 2.7$)$ & $1.8(0.1$ to 3.6$)$ & $2.3(0.5$ to 5.0$)$ & $0.8(-0.4$ to 2.0$)$ \\
\hline III skilled manual & 411 & $1.8(0.6$ to 3.1$)$ & $2.9(1.4$ to 4.5$)$ & 3.3 ( 0.8 to 5.8$)$ & $1.4(0.3$ to 2.5$)$ \\
\hline IV semi-skilled & 188 & 2.8 ( 1.4 to 4.3$)$ & $4.9(3.1$ to 6.6$)$ & $6.2(3.3$ to 9.0$)$ & $2.2(1.0$ to 3.5$)$ \\
\hline V unskilled & 37 & $3.8(1.5$ to 6.1$)$ & $6.1(3.2$ to 9.0$)$ & 8.0 ( 3.4 to 12.7$)$ & $2.3(0.3$ to 4.3$)$ \\
\hline Adult social class at 43 years & & $p \leqslant 0.001\left(p \leqslant 0.001^{*}\right)$ & $p \leqslant 0.001\left(p \leqslant 0.001^{*}\right)$ & $p \leqslant 0.001(p \leqslant 0.001 *)$ & $p \leqslant 0.001\left(p \leqslant 0.001^{*}\right)$ \\
\hline I professional (reference group) & 134 & $79.4(78.3$ to 80.5$) \%$ & $51.5(50.2$ to 52.9$) \%$ & $83.7(81.5$ to 85.8$) \mathrm{cm}$ & $26.7(25.7$ to 27.6$) \mathrm{kg} / \mathrm{m}^{2}$ \\
\hline II intermediate & 558 & $0.6(-0.6$ to 1.8$)$ & $0.5(-1.0$ to 2.0$)$ & $0.74(-1.7$ to 3.1$)$ & $0.2(-0.8$ to 1.3$)$ \\
\hline III skilled non-manual & 152 & $1.0(-0.5$ to 2.5$)$ & $1.4(-0.4$ to 3.3$)$ & $1.85(-1.1$ to 4.8$)$ & $0.4(-0.9$ to 1.6$)$ \\
\hline III skilled manual & 359 & $1.3(0.0$ to 2.6$)$ & $2.3(0.7$ to 3.9$)$ & $2.64(0.1$ to 5.2$)$ & $1.2(0.1$ to 2.3$)$ \\
\hline IV semi-skilled & 115 & $4.6(3.0$ to 6.2$)$ & $5.4(3.4$ to 7.4$)$ & 7.53 ( 4.4 to 10.7$)$ & $2.5(1.2$ to 3.9$)$ \\
\hline V unskilled & 27 & $2.4(-0.3$ to 5.1$)$ & $7.9(4.6$ to 11.2$)$ & 11.12 ( 5.9 to 16.4 ) & $5.1(2.8$ to 7.4$)$ \\
\hline
\end{tabular}

†Numbers are based on the model including waist-hip ratio and vary only slightly for the other obesity measures. *Test for trend.

\section{Adult social class}

In women, both adult social classes (at ages 26 and 43 years) were inversely associated with all obesity measures at age 53 years (table 1). After adjustment for all three measures of social class these associations remained for all but the relation between social class at 26 years and body mass index (table 2). By contrast in men, the associations observed in the unadjusted models between adult social class at ages 26 or 43 years and obesity (table 1) did not remain in the fully adjusted models, apart from a significant increasing trend in waist-hip ratio with decreasing social class at 43 years (table 2). There were significant sex differences in the effect of social class at 26 years on waist-height ratio ( $p=0.04$ for test for sex by social class interaction) and the effect of social class at 43 years on waist-hip ratio $(p=0.01)$, waist circumference $(p=0.01)$ and body mass index $(p=0.001)$, after adjustment for father's social class.

\section{Social mobility}

More cohort members experienced intergenerational upward social mobility (men $54.8 \%$, women $55.2 \%$ ) than downward social mobility (men $17.3 \%$, women $19.9 \%$ ) between father's social class and adult social class at 43 years. Over a quarter of men $(27.9 \%)$ and women $(24.9 \%)$ maintained their original social class. Mean levels of central and total obesity of the upwardly mobile, compared with those who stayed in the same class throughout their life course, are shown in table 3. There was significant variation in means across categories of this social mobility variable for all measures of obesity and for both men and women (table 3).

Among men and women who maintained their father's social class, those from social classes I and II had the lowest levels of all obesity measures. For example, the waist-hip ratio was $92.1 \%$ for men and $79.3 \%$ for women in these classes compared with $94.6 \%$ for men and $84.3 \%$ for women

Table 2A Adjusted results from multiple regression models including social class at all time points for men: differences in means (95\% confidence intervals) between each social class and the professional social class 1 (reference group)

\begin{tabular}{|c|c|c|c|c|}
\hline Men & $\begin{array}{l}\text { Waist-hip ratio (\%) } \\
(n=1299)\end{array}$ & $\begin{array}{l}\text { Waist-height ratio (\%) } \\
\text { ( } \mathrm{n}=1299 \text { ) }\end{array}$ & $\begin{array}{l}\text { Waist circumference }(\mathrm{cm}) \\
(\mathrm{n}=1300)\end{array}$ & $\begin{array}{l}\text { Body mass index }\left(\mathrm{kg} / \mathrm{m}^{2}\right) \\
(\mathrm{n}=1299)\end{array}$ \\
\hline Father's social class & $p=0.002(p=0.01)$ & $p=0.002\left(p=0.002^{*}\right)$ & $p=0.06\left(p=0.1^{*}\right)$ & $p=0.002\left(p=0.001^{*}\right)$ \\
\hline I professional (reference group) & 0 & 0 & 0 & 0 \\
\hline II intermediate & $0.3(-1.3$ to 1.9$)$ & $0.7(-1.0$ to 2.3$)$ & $1.3(-1.6$ to 4.1$)$ & $0.6(-0.5$ to 1.6$)$ \\
\hline III skilled non-manual & $1.1(-0.5$ to 2.7$)$ & $1.3(-0.3$ to 2.9$)$ & $1.8(-1.1$ to 4.6$)$ & $0.8(-0.2$ to 1.9$)$ \\
\hline III skilled manual & $2.3(0.7$ to 3.9$)$ & $2.6(1.0$ to 4.2$)$ & $3.6(0.8$ to 6.3$)$ & $1.7(0.7$ to 2.8$)$ \\
\hline IV semi-skilled & $1.1(-0.6$ to 2.7$)$ & $1.6(0.0$ to 3.3$)$ & $2.0(-0.9$ to 4.8$)$ & 1.1 ( 0.1 to 2.2$)$ \\
\hline V unskilled & $1.8(-0.2$ to 3.8$)$ & $2.3(0.3$ to 4.3$)$ & $2.1(-1.3$ to 5.6$)$ & $1.7(0.4$ to 3.0$)$ \\
\hline Adult social class at 26 years & $p=0.98\left(p=0.6^{*}\right)$ & $p=0.8\left(p=0.5^{\star}\right)$ & $p=0.7\left(p=0.7^{*}\right)$ & $p=0.6\left(p=0.5^{*}\right)$ \\
\hline I professional (reference group) & 0 & 0 & 0 & 0 \\
\hline II intermediate & $-0.1(-1.5$ to 1.3$)$ & $-0.0(-1.4$ to 1.3$)$ & $-1.4(-3.7$ to 1.0$)$ & $-0.2(-1.0$ to 0.7$)$ \\
\hline III skilled non-manual & $-0.2(-1.8$ to 1.3$)$ & $-0.5(-1.9$ to 1.0$)$ & $-1.7(-4.3$ to 0.9$)$ & $-0.3(-1.3$ to 0.6$)$ \\
\hline III skilled manual & $0.3(-1.2$ to 1.7$)$ & $0.3(-1.1$ to 1.8$)$ & $-0.9(-3.5$ to 1.7$)$ & $0.3(-0.7$ to 1.2$)$ \\
\hline IV semi-skilled & $-0.1(-1.7$ to 1.6$)$ & $-0.0(-1.7$ to 1.6$)$ & $-2.0(-4.9$ to 0.9$)$ & $-0.0(-1.1$ to 1.1$)$ \\
\hline V unskilled & $-0.0(-3.0$ to 2.9$)$ & $0.8(-2.2$ to 3.7$)$ & $-1.3(-6.4$ to 3.8$)$ & $-0.6(-2.5$ to 1.3$)$ \\
\hline Adult social class at 43 years & $p=0.2\left(p=0.007^{*}\right)$ & $p=0.6\left(p=0.3^{*}\right)$ & $p=0.5\left(p=0.3^{*}\right)$ & $\mathrm{p}=0.4\left(\mathrm{p}=0.8^{*}\right)$ \\
\hline I professional (reference group) & 0 & 0 & 0 & 0 \\
\hline II intermediate & $0.6(-0.7$ to 1.8$)$ & $0.8(-0.4$ to 2.1$)$ & $1.7(-0.5$ to 3.9$)$ & $0.5(-0.3$ to 1.3$)$ \\
\hline III skilled non-manual & $1.4(-0.3$ to 3.0$)$ & $1.2(-0.5$ to 2.8$)$ & $2.3(-0.6$ to 5.1$)$ & $0.6(-0.5$ to 1.6$)$ \\
\hline III skilled manual & $1.7(0.3$ to 3.2$)$ & $1.2(-0.3$ to 2.6$)$ & $2.2(-0.3$ to 4.7$)$ & $0.3(-0.6$ to 1.3$)$ \\
\hline IV semi-skilled & $1.2(-0.6$ to 3.0$)$ & $1.1(-0.7$ to 2.8$)$ & $2.1(-1.1$ to 5.2$)$ & $0.1(-1.1$ to 1.2$)$ \\
\hline V unskilled & $2.3(-0.7$ to 5.2$)$ & $-0.5(-3.4$ to 2.4$)$ & $-0.4(-5.5$ to 4.8$)$ & $-1.2(-3.1$ to 0.7$)$ \\
\hline
\end{tabular}

*Test for trend. 
Table 2B Adjusted results from multiple regression models including social class at all time points for women: differences in means ( $95 \%$ confidence intervals) between each social class and the professional social class 1 (reference group)

\begin{tabular}{|c|c|c|c|c|}
\hline Women & $\begin{array}{l}\text { Waist-hip ratio (\%) } \\
(n=1345)\end{array}$ & $\begin{array}{l}\text { Waist-height ratio (\%) } \\
\text { ( } n=1342 \text { ) }\end{array}$ & $\begin{array}{l}\text { Waist circumference }(\mathrm{cm}) \\
(\mathrm{n}=1347)\end{array}$ & $\begin{array}{l}\text { Body mass index }\left(\mathrm{kg} / \mathrm{m}^{2}\right) \\
(\mathrm{n}=1337)\end{array}$ \\
\hline $\begin{array}{l}\text { Father's social class } \\
\text { | professional (reference group) }\end{array}$ & $\begin{array}{l}p=0.2(p=0.02 *) \\
0\end{array}$ & $p \leqslant 0.001(p \leqslant 0.001 *)$ & $\begin{array}{l}p=0.001\left(p=0.003^{*}\right) \\
0\end{array}$ & $p \leqslant 0.001\left(p \leqslant 0.001^{*}\right)$ \\
\hline II intermediate & $-0.1(-1.8$ to 1.5$)$ & $0.3(-1.6$ to 2.3$)$ & $0.1(-3.1$ to 3.2$)$ & $0.0(-1.3$ to 1.4$)$ \\
\hline III skilled non-manual & $0.2(-1.4$ to 1.8$)$ & $-0.5(-2.4$ to 1.5$)$ & $-1.1(-4.2$ to 2.0$)$ & $-0.7(-2.1$ to 0.6$)$ \\
\hline III skilled manual & $0.4(-1.2$ to 1.9$)$ & $1.6(-0.3$ to 3.5$)$ & $1.5(-1.5$ to 4.5$)$ & $1.1(-0.2$ to 2.4$)$ \\
\hline IV semi-skilled & $1.2(-0.5$ to 2.8$)$ & $2.9(0.9$ to 4.9$)$ & $3.7(0.5$ to 6.9$)$ & $1.5(0.2$ to 2.9$)$ \\
\hline V unskilled & $1.4(-0.6,3.4)$ & $2.1(-0.4$ to 4.5$)$ & $1.7(-2.2$ to 5.6$)$ & $0.6(-1.1$ to 2.3$)$ \\
\hline Adult social class at 26 years & $p=0.04\left(p=0.003^{*}\right)$ & $p=0.004\left(p \leqslant 0.001^{*}\right)$ & $p=0.05\left(p=0.01^{*}\right)$ & $P=0.5\left(p=0.1^{*}\right)$ \\
\hline I professional (reference group) & 0 & 0 & 0 & 0 \\
\hline II intermediate & $-0.2(-1.6$ to 1.2$)$ & $0.0(-1.7$ to 1.7$)$ & $0.0(-2.7$ to 2.7$)$ & $0.0(-1.1$ to 1.2$)$ \\
\hline III skilled non-manual & $0.9(-0.6$ to 2.4$)$ & $1.0(-0.8$ to 2.9$)$ & $1.2(-1.8$ to 4.1$)$ & $0.4(-0.9$ to 1.6$)$ \\
\hline III skilled manual & $1.0(-0.4$ to 2.5$)$ & $1.4(-0.5$ to 3.2$)$ & $1.2(-1.6$ to 4.1$)$ & $0.5(-0.8$ to 1.7$)$ \\
\hline IV semi-skilled & $1.7(0.1$ to 3.3$)$ & $2.9(1.0$ to 4.9$)$ & $3.6(0.4$ to 6.7$)$ & $1.1(-0.2$ to 2.5$)$ \\
\hline$\checkmark$ unskilled & $2.2(-0.4$ to 4.7$)$ & $3.4(0.3$ to 6.5$)$ & $4.4(-0.5$ to 9.2$)$ & $0.8(-1.3$ to 2.9$)$ \\
\hline $\begin{array}{l}\text { Adult social class at } 43 \text { years } \\
\text { I professional (reference group) }\end{array}$ & $\begin{array}{l}p \leqslant 0.001(p=0.02 *) \\
0\end{array}$ & $\begin{array}{l}p \leqslant 0.001(p \leqslant 0.001 *) \\
0\end{array}$ & $\begin{array}{l}p=0.001\left(p=0.002^{*}\right) \\
0\end{array}$ & $\begin{array}{l}p \leqslant 0.001(p \leqslant 0.001 *) \\
0\end{array}$ \\
\hline II intermediate & $0.4(-0.9$ to 1.7$)$ & $0.2(-1.4$ to 1.7$)$ & $0.3(-2.2$ to 2.8$)$ & $0.1(-1.0$ to 1.2$)$ \\
\hline III skilled non-manual & $0.3(-1.3$ to 1.9$)$ & $0.3(-1.7$ to 2.3$)$ & $0.5(-2.7$ to 3.6$)$ & $-0.1(-1.5$ to 1.2$)$ \\
\hline III skilled manual & $0.2(-1.3$ to 1.7$)$ & 0.5 (-1.3 to 2.2$)$ & $0.5(-2.3$ to 3.4$)$ & $0.4(-0.8$ to 1.6$)$ \\
\hline IV semi-skilled & $3.3(1.6$ to 5.1$)$ & $3.2(1.0$ to 5.3$)$ & $4.8(1.4$ to 8.3$)$ & $1.6(0.1$ to 3.0$)$ \\
\hline V unskilled & $1.3(-1.5$ to 4.0$)$ & $5.8(2.5$ to 9.2$)$ & $8.6(3.2$ to 13.9$)$ & $4.2(1.9$ to 6.5$)$ \\
\hline
\end{tabular}

in classes IV or V (table 3). Obesity levels of upwardly mobile men and women tended to be between the class they left and the class they joined. We found that men and women who experienced the greatest upward social mobility (participants from social class IV or V who moved up to classes I or II) had lower levels than study members from these classes (IV or V) who only moved up to class III non-manual or III manual (table 3). These findings were only marginally affected by adjustment for smoking and exercise (results not shown).

The analysis of downward mobility (using non-manual and manual categories) showed that those who moved down had higher means for all obesity measures than those who remained in non-manual occupations, but lower means than those who had always been in manual occupations (table 4).

\section{DISCUSSION}

\section{Summary of results}

In this study father's social class at 4 years of age influenced central and total obesity at age 53 years after adjustment for own social class in young adulthood and middle age. Independent effects of both adult social classes on obesity were also present in women, but not men. For example, this cumulative effect of lifetime socioeconomic circumstances on women's obesity represents a difference of $4.9 \%$ for waist-hip ratio or $5.6 \mathrm{~kg} / \mathrm{m}^{2}$ for body mass index between women in the most advantaged compared with those in the least advantaged circumstances. Men and women who experienced upward intergenerational social mobility had lower levels of central and total obesity compared with those who

Table 3A Upward mobility between father's and own adult social class at 43 years for men: mean obesity levels (95\% confidence intervals) for the upwardly mobile and those who remained in the same social class

\begin{tabular}{|c|c|c|c|c|}
\hline \multirow[b]{2}{*}{ Men } & \multicolumn{4}{|l|}{ Adult social class } \\
\hline & I, II & III non-manual & III manual & IV, V \\
\hline $\begin{array}{l}\text { Father's social class } \\
\text { Waist-hip ratio (\%) } \\
\text { Class I and II }\end{array}$ & $\begin{array}{l}p \leqslant 0.001 \\
n=234^{*} \\
92.1(91.3 \text { to } 92.9)\end{array}$ & & & \\
\hline Class III non-manual & $\begin{array}{l}\mathrm{n}=170 \\
92.8(91.8 \text { to } 93.7)\end{array}$ & $\begin{array}{l}n=36 \\
93.9(91.8 \text { to } 95.9)\end{array}$ & & \\
\hline Class III manual & $\begin{array}{l}n=182 \\
94.0(93.1 \text { to } 94.9)\end{array}$ & $\begin{array}{l}n=37 \\
94.5(92.5 \text { to } 96.5)\end{array}$ & $\begin{array}{l}n=144 \\
95.9(94.8 \text { to } 96.9)\end{array}$ & \\
\hline Class IV and V & $\begin{array}{l}n=134 \\
92.7(91.7 \text { to } 93.8)\end{array}$ & $\begin{array}{l}n=31 \\
94.5(92.3 \text { to } 96.6)\end{array}$ & $\begin{array}{l}n=155 \\
94.2(93.3 \text { to } 95.2)\end{array}$ & $\begin{array}{l}n=59 \\
94.6(93.0 \text { to } 96.2)\end{array}$ \\
\hline $\begin{array}{l}\text { Waist-height ratio (\%) } \\
\text { Class I and II }\end{array}$ & $\begin{array}{l}p \leqslant 0.001 \\
54.7(53.9 \text { to } 55.4)\end{array}$ & & & \\
\hline Class III non-manual & $55.0(54.1$ to 55.9$)$ & 55.9 (53.9 to 57.9$)$ & & \\
\hline Class III manual & 57.1 (56.2 to 58.0$)$ & 56.7 (54.7 to 58.6$)$ & $57.6(56.6$ to 58.6$)$ & \\
\hline $\begin{array}{l}\text { Class IV and V } \\
\text { Waist circumference }(\mathrm{cm})\end{array}$ & $\begin{array}{l}55.6(54.6 \text { to } 56.6) \\
p=0.02\end{array}$ & 56.6 (54.4 to 58.7$)$ & $56.4(55.5$ to 57.4$)$ & $57.2(55.6$ to 58.7$)$ \\
\hline Class I and II & $96.6(95.2$ to 98.0$)$ & & & \\
\hline Class III non-manual & $96.5(94.9$ to 98.1$)$ & $98.5(95.0$ to 102.1$)$ & & \\
\hline Class III manual & 99.4 (97.8 to 100.9$)$ & 97.8 (94.3 to 101.3$)$ & $100.2(98.4$ to 101.9$)$ & \\
\hline $\begin{array}{l}\text { Class IV and V } \\
\text { Body mass index }\left(\mathrm{kg} / \mathrm{m}^{2}\right)\end{array}$ & $\begin{array}{l}96.5(94.7 \text { to } 98.3) \\
p \leqslant 0.001\end{array}$ & 99.2 (95.4 to 103.0$)$ & 97.6 (95.9 to 99.3$)$ & 98.8 (96.1 to 101.5$)$ \\
\hline Class I and II & 26.7 (26.2 to 27.2 ) & & & \\
\hline Class III non-manual & 26.8 (26.2 to 27.4$)$ & 27.0 (25.7 to 28.3$)$ & & \\
\hline Class III manual & 28.3 (27.7 to 28.9 ) & 27.8 (26.6 to 29.1$)$ & 28.2 (27.5 to 28.8 ) & \\
\hline Class IV and V & 27.4 (26.7 to 28.1$)$ & 27.9 (26.5 to 29.3$)$ & 27.6 (26.9 to 28.2 ) & 27.7 (26.6 to 28.7 ) \\
\hline
\end{tabular}


Table 3B Upward mobility between father's and own adult social class at 43 years for women: mean obesity levels $195 \%$ confidence intervals) for the upwardly mobile and those who remained in the same social class

\begin{tabular}{|c|c|c|c|c|}
\hline \multirow[b]{2}{*}{ Women } & \multicolumn{4}{|l|}{ Adult social class } \\
\hline & I, II & III non-manual & III manual & IV, V \\
\hline $\begin{array}{l}\text { Father's social class } \\
\text { Waist-hip ratio (\%) } \\
\text { Class I and II }\end{array}$ & $\begin{array}{l}p \leqslant 0.001 \\
n=220^{*} \\
79.3 \text { (78.5 to } 80.2)\end{array}$ & & & \\
\hline Class III non-manual & $\begin{array}{l}n=171 \\
79.7(78.7 \text { to } 80.7)\end{array}$ & $\begin{array}{l}n=31 \\
81.2(78.9 \text { to } 83.5)\end{array}$ & & \\
\hline Class III manual & $\begin{array}{l}n=196 \\
80.1(79.2 \text { to } 81.0)\end{array}$ & $\begin{array}{l}n=42 \\
79.2(77.2 \text { to } 81.1)\end{array}$ & $\begin{array}{l}n=135 \\
81.0(79.9 \text { to } 82.1)\end{array}$ & \\
\hline Class IV and V & $\begin{array}{l}n=130 \\
81.0(79.9 \text { to } 82.1)\end{array}$ & $\begin{array}{l}n=46 \\
81.6(79.7 \text { to } 83.5)\end{array}$ & $\begin{array}{l}n=134 \\
81.4(80.3 \text { to } 82.5)\end{array}$ & $\begin{array}{l}\mathrm{n}=58 \\
84.3(82.6 \text { to } 86.0)\end{array}$ \\
\hline $\begin{array}{l}\text { Waist-height ratio (\%) } \\
\text { Class I and II }\end{array}$ & $\begin{array}{l}p \leqslant 0.001 \\
51.2(50.1 \text { to } 52.2)\end{array}$ & & & \\
\hline Class III non-manual & 50.3 (49.1 to 51.5 ) & 51.9 (49.1 to 54.7$)$ & & \\
\hline Class III manual & 52.7 (51.6 to 53.8 ) & $53.0(50.6$ to 55.4$)$ & 54.1 (52.8 to 55.4$)$ & \\
\hline $\begin{array}{l}\text { Class IV and V } \\
\text { Waist circumference }(\mathrm{cm})\end{array}$ & $\begin{array}{l}54.1(52.7 \text { to } 55.4) \\
p \leqslant 0.001\end{array}$ & 54.8 (52.6 to 57.0$)$ & $54.9(53.5$ to 56.2$)$ & 59.6 (57.6 to 61.6$)$ \\
\hline $\begin{array}{l}\text { Waist circumference (cm) } \\
\text { Class I and II }\end{array}$ & $\begin{array}{l}p \leqslant 0.00 \\
83.8(82.1 \text { to } 85.4)\end{array}$ & & & \\
\hline Class III non-manual & $82.0(80.1$ to 83.9$)$ & 84.2 (79.8 to 88.6 ) & & \\
\hline Class III manual & 85.0 (83.2 to 86.7$)$ & 85.0 (81.2 to 88.8$)$ & 86.7 (84.5 to 88.8 ) & \\
\hline $\begin{array}{l}\text { Class IV and V } \\
\text { Body mass index }\left(\mathrm{kg} / \mathrm{m}^{2}\right)\end{array}$ & $86.9(84.7$ to 89.1$)$ & 89.2 (85.6 to 92.7 ) & 87.5 ( 85.4 to 89.6$)$ & 94.9 (91.7 to 98.2$)$ \\
\hline $\begin{array}{l}\text { Body mass index }\left(\mathbf{k g} / \mathrm{m}^{2}\right) \\
\text { Class I and II }\end{array}$ & $\begin{array}{l}p \leqslant 0.001 \\
26.5(25.8 \text { to } 27.2)\end{array}$ & & & \\
\hline Class III non-manual & 25.5 (24.6 to 26.3 ) & 26.4 (24.5 to 28.3 ) & & \\
\hline Class III manual & 27.5 (26.7 to 28.2 ) & 27.5 ( 25.9 to 29.1$)$ & 28.2 (27.2 to 29.1$)$ & \\
\hline Class IV and V & 28.1 ( 27.2 to 29.0$)$ & 27.9 (26.4 to 29.4 ) & 28.2 (27.3 to 29.1$)$ & 30.8 (29.4 to 32.2$)$ \\
\hline
\end{tabular}

Table 4 Upward and downward mobility between father's and own adult social class at 43 years: mean obesity levels $195 \%$ confidence intervals) of socially mobile participants and those who remained in the same social class (using manual and nonmanual categorisation of social class)

\begin{tabular}{|c|c|c|c|c|}
\hline \multirow[b]{3}{*}{ Father's social class } & \multicolumn{2}{|l|}{ Men } & \multicolumn{2}{|l|}{ Women } \\
\hline & \multicolumn{2}{|l|}{ Adult social class } & \multicolumn{2}{|l|}{ Adult social class } \\
\hline & Non-manual & Manual & Non-manual & Manual \\
\hline Waist-hip ratio (\%) & $p \leqslant 0.001$ & & $p \leqslant 0.001$ & \\
\hline Non-manual & $\begin{array}{l}n=458^{*} \\
92.5(91.1 \text { to } 93.0)\end{array}$ & $\begin{array}{l}\mathrm{n}=106 \\
93.4(92.2 \text { to } 94.6)\end{array}$ & $\begin{array}{l}n=460 \\
79.6(79.0 \text { to } 80.2)\end{array}$ & $\begin{array}{l}n=135 \\
80.5(79.4 \text { to } 81.6)\end{array}$ \\
\hline Manual & $\begin{array}{l}\mathrm{n}=384 \\
93.6(93.0 \text { to } 94.3)\end{array}$ & $\begin{array}{l}n=401 \\
94.9(94.3 \text { to } 95.5)\end{array}$ & $\begin{array}{l}n=414 \\
80.4(79.8 \text { to } 81.1)\end{array}$ & $\begin{array}{l}\mathrm{n}=376 \\
81.9(81.3 \text { to } 82.6)\end{array}$ \\
\hline Waist-height ratio (\%) & $p \leqslant 0.001$ & & $p \leqslant 0.001$ & \\
\hline Non-manual & $54.8(54.3$ to 55.4$)$ & 55.8 (54.6 to 56.9 ) & $50.9(50.2$ to 51.7$)$ & 52.8 (51.4 to 54.2$)$ \\
\hline Manual & 56.5 (55.9 to 57.1$)$ & $56.8(56.3$ to 57.4$)$ & 53.4 (52.6 to 54.2$)$ & 55.7 (54.9 to 56.5$)$ \\
\hline $\begin{array}{l}\text { Waist circumference }(\mathrm{cm}) \\
\text { Non-manual }\end{array}$ & $\begin{array}{l}p=0.048 \\
96.6(95.6 \text { to } 97.6)\end{array}$ & 97.3 (95.3 to 99.4 ) & $\begin{array}{l}p \leqslant 0.001 \\
83.1(81.9 \text { to } 84.2)\end{array}$ & 85.2 (83.1 to 87.4$)$ \\
\hline $\begin{array}{l}\text { Manual } \\
\text { Body mass index }\left(\mathrm{kg} / \mathrm{m}^{2}\right)\end{array}$ & $\begin{array}{l}98.2(97.1 \text { to } 99.3) \\
p \leqslant 0.001\end{array}$ & 98.5 (97.5 to 99.6$)$ & $\begin{array}{l}86.1(84.8 \text { to } 87.3) \\
p \leqslant 0.001\end{array}$ & 89.0 (87.7 to 90.3$)$ \\
\hline Non-manual & $26.8(26.4$ to 27.1$)$ & 27.2 (26.4 to 27.9 ) & $26.1(25.6$ to 26.6$)$ & $27.2(26.3$ to 28.1$)$ \\
\hline Manual & 27.9 (27.5 to 28.3$)$ & 27.7 (27.3 to 28.1$)$ & 27.7 (27.2 to 28.2$)$ & 28.8 (28.3 to 29.4$)$ \\
\hline
\end{tabular}

*Numbers are based on the model including waist-hip ratio and vary only slightly for the other obesity measures.

remained in the same social class as their father, and this effect was not attenuated by adjustment for smoking and exercise.

\section{Comparison with other studies}

Two studies investigated the effects of early and adult socioeconomic position on central obesity. ${ }^{16}{ }^{18}$ Unlike our study, Brunner et al 1999 showed associations of own employment grade with adult central and total obesity after adjustment for father's social class in men. ${ }^{18}$ This may be because the Whitehall II study is an occupational rather than a population cohort. All participants were in the non-manual classes and childhood classes were thus unlikely to be representative. Reports of childhood social class were also retrospective and prone to recall bias. Using prospective longitudinal data and a representative spectrum of father's occupations, we confirm the findings of studies of women that have shown effects of father's and adult social class on central and total obesity. ${ }^{16}$ Our findings for men are consistent with those of Blane et al who showed an association of father's social class (measured retrospectively), but not adult social class, with adult body mass index. ${ }^{17}$

Most other studies of the influence of social class and mobility on obesity have not used measures of central obesity, or not adjusted father's for adult social class, and vice versa. Some authors considered more than two time points to assess the influence of social class experience on adult mortality and its risk factors across the life course, and allocated a score to each social class group (for example, 1 for non-manual and 2 for manual occupations) at each time point, and summed these into an overall score. ${ }^{21}{ }^{22}$ It has been 
argued that the use of a cumulative class score is a sufficient indicator of class experience over the life course and that the direction of mobility is not important for overall mortality.21 Our results suggest that such an approach may not be appropriate for obesity outcomes because the effect of father's social class is generally stronger than the effect of adult social class, particularly in men. Except in the case of waist-hip ratio, only father's social class was significantly associated with obesity measures in the multiple regression models in men, indicating that early social circumstances and consequently the direction of social class change have an important influence on the development of adult obesity. Our findings also suggest that categorising social class into only manual and non-manual groups results in a loss of important information, as levels of central and total obesity were lower in participants from social class IV and V who moved to class I and II compared with those from classes IV and V who moved up to a lesser extent.

\section{Gender differences}

Our results suggest that low social class has detrimental effects on women's obesity throughout adult life, whereas in men childhood class experience seems to be particularly important. There are sex differences in the prevalence of overweight and obesity, of weight gain, and of change of body shape after puberty. ${ }^{24}$ Genetic and environmental factors, childbirth, hormonal changes, and health behaviour, some of which are influenced by social position, contribute to these differences, ${ }^{25}$ and may explain our differential results for social class. ${ }^{26-28}$ Men who remained in both generations in the skilled manual class had higher levels of central and total obesity than those remaining in the semi-skilled or unskilled occupations. In women the greatest levels of obesity were seen in those remaining in the lowest classes. It may be that the increase of earnings and purchasing power of men in this social group, have not been accompanied by an equivalent adaptation to a healthier lifestyle. Equally, participants who remained in the lowest classes during times of general advancement may represent a particularly underprivileged group. Social and economic disadvantage, especially unemployment, has been associated with high body mass index in women, but thinness (body mass index $<20 \mathrm{~kg} / \mathrm{m}^{2}$ ) in men. ${ }^{29}$

\section{Study limitations}

The life course analysis of social class on adult obesity is complex, because social classes at different time points are related to each other. We encountered no statistical problems in fitting the multiple regression models including all three measures of social class, suggesting that multicollinearity was not a problem in our analyses.

Social class is only an approximation of many influences on health, which may be causal for the development of certain diseases. The summary into non-manual and manual classes is a simplification, which does not allow for the testing of a linear gradient across all classes. We had to use such a classification to consider the effects of downward social mobility on obesity, because downward mobility was uncommon in this generation. The use of a conventional household class measure (partner's social class) for women assumes that their social and financial position and class awareness are more closely linked to their partner's than their own occupation. Few women were employed in early adulthood in this cohort, and we could not meaningfully assign women to their own social class based on an occupation that many only held for a very limited time and often never returned to.

There are limitations in these findings, in terms of extrapolation of results to later generations. Few children in this study were obese or overweight, ${ }^{30}$ compared with later

\section{Key points}

- Father's social class is inversely associated with adult central and total obesity, after adjustment for social class at 26 and 43 years.

- In women, but not men, adult social class is inversely related to obesity, after accounting for childhood circumstances.

- Upwardly mobile men and women are less obese than participants remaining in the same social class as their fathers.

- Our results on intergenerational mobility indicate the potential reversibility of early life disadvantage on obesity.

cohorts and the intragenerational and intergenerational social mobility among this generation was high. ${ }^{31}$

\section{Public health implications}

Upward intergenerational mobility was associated with lower obesity at age 53 years, suggesting that the long term influence of childhood social class on central and total obesity may be partly reversible. The observation of gender differences, and detection of sensitive time points for the development of social class differences in adult obesity is important to plan timely and gender specific public health interventions.

Social position influences the risk of coronary heart disease and obesity, and Great Britain is one of the industrial nations with the greatest income inequality. ${ }^{32}$ The decline in mortality rates in cardiovascular disease and the distribution of risk factors differs by occupational status. ${ }^{33-35}$ Any intervention that aims to target the high risk groups should consider this class gradient, particularly as obesity levels are increasing rapidly.

\section{ACKNOWLEDGEMENTS}

The MRC National Survey of Health and Development has been supported almost entirely by grants from the Medical Research Council. CL is supported by a grant from the RAND Corporation of America to the Medical Research Council; RH, DK and MW are supported by the Medical Research Council and EB is supported by the British Heart Foundation.

\section{Authors' affiliations}

C Langenberg, R Hardy, D Kuh, M Wadsworth, MRC National Survey of Health and Development, London, UK

E Brunner, International Centre for Health and Society; Department of Epidemiology and Public Health, University College London

Conflicts of interest: none declared.

\section{REFERENCES}

1 World Health Organisation. Obesity: preventing and managing the global epidemic. Geneva: WHO technical report series no 894, 2000.

2 Ohlson LO, Larsson B, Svardsudd K, et al. The influence of body fat distribution on the incidence of diabetes mellitus. 13.5 years of follow-up of the participants in the study of men born in 1913. Diabetes 1985;34:1055-8.

3 Manson JE, Willett WC, Stampfer MJ, et al. Body weight and mortality among women. N Engl J Med 1995;333:677-85.

4 Baik I, Ascherio A, Rimm EB, et al. Adiposity and mortality in men. Am J Epidemiol 2000; 152:264-71

5 Lapidus L, Bengtsson C, Larsson B, et al. Distribution of adipose tissue and risk of cardiovascular disease and death: a 12 year follow up of participants in the population study of women in Gothenburg, Sweden. BMJ 1984;289:1257-61.

6 Rimm EB, Stampfer MJ, Giovannucci E, et al. Body size and fat distribution as predictors of coronary heart disease among middle-aged and older US men. Am J Epidemiol 1995;141:1117-27. 
7 Rexrode KM, Carey VJ, Hennekens $\mathrm{CH}$, et al. Abdominal adiposity and coronary heart disease in women. JAMA 1998;280:1843-8.

8 Sobal J, Stunkard AJ. Socioeconomic status and obesity: a review of the literature. Psychol Bull 1989;105:260-75.

9 Parsons TJ, Power C, Logan S, et al. Childhood predictors of adult obesity: a systematic review. Int J Obes Relat Metab Disord 1999;23:S1-107.

10 Hardy R, Wadsworth M, Kuh D. The influence of childhood weight and socioeconomic status on change in adult body mass index in a British national birth cohort. Int J Obes Relat Metab Disord 2000;24:725-34.

11 Brunner EJ, Marmot MG, Nanchahal K, et al. Social inequality in coronary risk: central obesity and the metabolic syndrome. Evidence from the Whitehall II study. Diabetologia 1997;40:1341-9.

12 Rosmond R, Lapidus L, Bjorntorp P. The influence of occupational and social factors on obesity and body fat distribution in middle-aged men. Int J Obes Relat Metab Disord 1996;20:599-607.

13 Rosmond R, Bjorntorp P. Psychosocial and socio-economic factors in women and their relationship to obesity and regional body fat distribution. Int $J$ Obes Relat Metab Disord 1999:23:138-45.

14 Brunner $E$, Juneja $M$, Marmot $M$. Abdominal obesity and disease are linked to social position. BMJ 1998;316:308-9.

15 Wardle J, Waller J, Jarvis MJ. Sex differences in the association of socioeconomic status with obesity. Am J Public Health 2002;92:1299-304.

16 Lahmann PH, Lissner L, Gullberg B, et al. Sociodemographic factors associated with long-term weight gain, current body fatness and central adiposity in Swedish women. Int J Obes Relat Metab Disord 2000;24:685-94.

17 Blane D, Hart CL, Davey Smith G, et al. Association of cardiovascular disease risk factors with socioeconomic position during childhood and during adulthood. BMU 1996:313:1434-8.

18 Brunner E, Shipley MJ, Blane D, et al. When does cardiovascular risk start? Past and present socioeconomic circumstances and risk factors in adulthood. $J$ Epidemiol Community Health 1999;53:757-64.

19 Krieger N, Chen JT, Selby JV. Comparing individual-based and householdbased measures of social class to assess class inequalities in women's health: a methodological study of 684 US women. J Epidemiol Community Health 1999;53:612-23.

20 Wannamethee SG, Whincup PH, Shaper G, et al. Influence of fathers' social class on cardiovascular disease in middle- aged men. Lancet 1996;348:1259-63.

21 Davey Smith G, Hart C, Blane D, et al. Lifetime socioeconomic position and mortality: prospective observational study. BMJ 1997;314:547-52
22 Heslop P Davey Smith G, Macleod J, et al. The socioeconomic position of employed women, risk factors and mortality. Soc Sci Med 2001;53:477-85.

23 Wadsworth ME, Mann SL, Rodgers B, et al. Loss and representativeness in a 43 year follow up of a national birth cohort. J Epidemiol Community Health 1992:46:300-4

24 Lemieux S, Prud'homme D, Bouchard C, et al. Sex differences in the relation of visceral adipose tissue accumulation to total body fatness. Am J Clin Nutr 1993:58:463-7.

25 Lovejoy JC. The influence of sex hormones on obesity across the female life span. J Womens Health 1998;7:1247-56.

26 Nelson TL, Vogler GP, Pedersen NL, et al. Genetic and environmental influences on waist-to-hip ratio and waist circumference in an older Swedish twin population. Int J Obes Relat Metab Disord 1999;23:449-55.

27 Rose KM, Newman B, Mayer-Davis EJ, et al. Genetic and behavioral determinants of waist-hip ratio and waist circumference in women twins. Obes Res 1998;6:383-92.

28 Biorkelund C, Lissner L, Andersson S, et al. Reproductive history in relation to relative weight and fat distribution. Int J Obes Relat Metab Disord 1996;20:213-19.

29 Sarlio-Lahteenkorva $S$ Lahelma E. The association of body mass index with social and economic disadvantage in women and men. Int J Epidemiol 1999;28:445-9

30 Braddon FE, Rodgers B, Wadsworth ME, et al. Onset of obesity in a 36 year birth cohort study. BMJ 1986;293:299-303.

31 Halsey AH, Heath AF, Ridge JM. Origins and destinations. Oxford: Clarendon Press, 1980

32 Smeeding TM. Changing income inequality in OECD countries: updated results from the Luxembourg Income Study (LIS). In: Hanser R, Becker I, eds. The personal distribution of income in an international perspective. Berlin: Springer-Verlag, 2000.

33 Kunst AE, Groenhof F, Mackenbach JP, et al. Occupational class and cause specific mortality in middle aged men in 11 European countries: comparison of population based studies. EU Working Group on Socioeconomic Inequalities in Health. BMJ 1998;316:1636-42

34 Kaplan GA, Keil JE. Socioeconomic factors and cardiovascular disease: a review of the literature. Circulation 1993:88:1973-98.

35 Osler M, Gerdes LU, Davidsen M, et al. Socioeconomic status and trends in risk factors for cardiovascular diseases in the Danish MONICA population, 1982-1992. J Epidemiol Community Health 2000;54:108-13. 